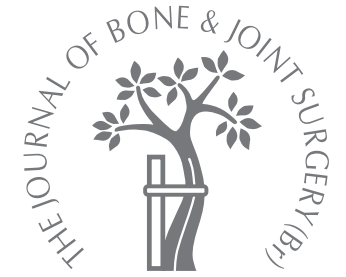

\section{Lidgren}

From Lund

University, Lund, Sweden
L. Lidgren, MD, PhD, Honorary FRCS, Professor Department of Orthopaedics and Clinical Sciences, Lund University Hospital, SE-221 85 Lund, Sweden.

Correspondence should be sent to Professor L. Lidgren; e-mail: Lars.Lidgren@med.lu.se

(C)2008 British Editorial Society of Bone and Joint Surgery doi:10.1302/0301-620X.90B1 $19823 \$ 2.00$

$J$ Bone Joint Surg $[\mathrm{Br}]$ 2008;90-B:7-10.

Received 15 June 2007,

Accepted after revision 30

August 2007

- ASPECTS OF CURRENT MANAGEMENT

\title{
Chronic inflammation, joint replacement and malignant lymphoma
}

This paper considers the increased risk of the development of lymphoma in patients with chronic inflammatory disease who undergo metal-on-metal arthroplasty.

Patients with inflammatory conditions have twice the risk of developing lymphoma. This seems to be further increased if they have a metal-on-metal joint replacement. Prospective studies should be undertaken in patients with chronic systemic inflammatory conditions after the implantation of a metal-on-metal implant to investigate lymphocyte function and the risk of developing haematopoietic malignancies.

\section{Register studies}

One method of analysing the risk of developing lymphoma after joint replacement would be to screen large cohorts of patients for tumours over an extended period. The Scandinavian joint registers and national cancer statistics make this possible, but there are difficulties with the statistical evaluation of this type of study. ${ }^{1}$

Lewold et $\mathrm{al}^{2}$ from Sweden and Paavolainen et $\mathrm{al}^{3}$ from Finland reported a significant increase in lymphoma after knee replacement. In the Swedish study, osteoarthritis (OA) and rheumatoid arthritis (RA) were separated. Men with RA, followed for 3180 person years, had the highest risk of a lymphoma with a standardised rate of mortality (observed $v s$ expected) of 4.7 after 60 months. ${ }^{2}$ There was no increase in patients with OA. In the Finnish study with a mixed population the standardised incidence rate was 1.4 for non-Hodgkin's lymphoma. ${ }^{3}$

In a Danish study of hip and knee replacement for OA, no increase in haematopoietic cancer was found. ${ }^{4}$ Gillespie et $\mathrm{al}^{5}$ from New Zealand and Visuri et $\mathrm{al}^{6}$ from Finland found a three- to fourfold risk for tumours of the lymphatic and haematopoietic systems after total hip replacement (THR) compared with that in a community control group, but neither study separated OA from RA. Two other studies using patient admission registers to investigate the relationship between THR and cancer found no significant increase in lymphatic tumours. ${ }^{7,8}$ The highest risk of lymphoma (standardised incidence rate 4) was found in a Finnish study which analysed a metal-on-metal replacement, namely the Mckee-Farrar implant. ${ }^{9}$ None of these studies, however, separated OA from chronic inflammation. It is notable that RA, with the highest risk of the development of lymphoma, is present in only $3 \%$ to $5 \%$ of an arthroplasty population. ${ }^{10,11}$ The high risks of development of lymphoma in RA were confirmed by studies on rheumatoid patients and from the Swedish cancer register ${ }^{12}$ analysing haematopoietic malignancies, which verified earlier studies that showed patients with RA had more than twice the risk of developing lymphoma than community control groups. ${ }^{13-16}$ It is not clear whether modern treatment with tumour necrosis factor (TNF)-blocking agents or methotrexate increases the risk for lymphoma or if this is simply an effect of advanced disease. ${ }^{13-16}$ Recent data have also suggested a doubled risk in patients with systemic lupus erythematosus. ${ }^{17}$ The highest risk is in those with Sjögren's syndrome, in which $10 \%$ develop lymphoma, ${ }^{18,19}$ and when lymphoma predictors such as the $\mathrm{CD} 4+/ \mathrm{CD} 8+$ ratio were used the risk increased to over $30 \%{ }^{20}$

There are no register-cohort studies on the relative risk (standardised incidence rate or rate of mortality) of lymphoma in patients with a chronic systemic inflammatory condition, with reference to the activity and stage of the disease and whether the patient had undergone arthroplasty, especially a metal-on-metal prosthesis. This could only be done by cross-referencing different registers and probably only in the Nordic countries where personal identification numbers are used and arthroplasties have been registered for more than 30 years. ${ }^{10,11}$ 


\section{Cellular toxicity and the immune system}

There are many tests for studying the carcinogenic effects of new materials for clinical use in cell or bacterial cultures. The toxicity of cobalt and chromium, both of which constitute an important part of prosthetic alloys, is well documented. ${ }^{21-25}$ In tribological failures with catastrophic wear this may even lead to systemic cobalt poisoning. ${ }^{26}$

The most important questions are whether safe levels of metal ions can be determined for successful implants and if there are subgroups of patients with joint replacements who are at an increased risk of developing tumours, especially of the lymphatic system. ${ }^{27-29}$

Occupational environmental and animal testing data are of limited value, and ultimately clinical data on patients are required. ${ }^{30} \mathrm{~A}$ recent review has summarised the potential toxicity of metals released from alloys used in modern orthopaedics. ${ }^{31}$ As far as can be estimated from published clinical studies, the only combination which is likely to give significantly increased ion levels under normal conditions is cobalt-chromium alloys articulating against themselves. ${ }^{32}$ With the renewed popularity of metal-on-metal bearings, especially in younger patients, the focus has hitherto been on measuring cobalt ion concentrations in blood and urine. However, whether such measurements should be made on whole blood, plasma, serum or erythrocytes in addition to urine is unclear. ${ }^{33} \mathrm{~A}$ recent study has indicated that serum and whole blood levels are not equivalent. ${ }^{34}$

Retrieval analysis of metal-on-metal explants has shown, after a post-operative run-in period, annual wear of up to $5 \mu \mathrm{m} .{ }^{35}$ In such patients, the serum cobalt levels were three to five times higher than those of control subjects. ${ }^{35}$ In some studies, there was a late (four years) reduction of chromium but not of cobalt ions. ${ }^{36}$ New sensitive and reliable methods of determining trace metals by high-resolution inductivelycoupled plasma mass spectrometry have stimulated longterm repeated measurements. ${ }^{37-40}$ It could be inferred that patients with metal-on-metal implants have significantly higher serum and urine cobalt concentrations in the longterm than those with conventional metal-on-polyethylene bearings. ${ }^{41-44}$ Loose metal-on-metal implants may raise the level by factors of 50 to 300 compared with control groups. ${ }^{45}$ It has also been shown that there is a reversible exercise-related rise in plasma cobalt levels ${ }^{46,47}$ with variation between different metal-on-metal devices and sizes of femoral head. ${ }^{48-50}$ In a study on ten women with a metalon-metal implant, transplacental transfer and increased levels of cobalt were found in the umbilical cords of their infants. ${ }^{51}$

A recent report of 73 patients with metal-on-metal THRs showed an excellent probability of prosthetic survival at a minimum follow-up of ten years. ${ }^{52}$ Elevated serum metal levels were found by atomic absorption spectrometry which is less reliable, but were the same at short and intermediate follow-up. The authors reported four primary malignancies and stated that there was no evidence of increased risk. However, only $4 \%$ of their patients had an inflammatory arthritis. Wear particles from peri-prosthetic tissue after metal-on-metal implantation have been analysed by Catelas et $\mathrm{al}^{53}$ up to two years post-operatively. Rounded chromium particles were seen initially, and subsequently a greater proportion of cobalt-chromiummolybdenum particles were found. In one study, a prominent feature in the tissue of patients with metal-on-metal implants was perivascular particle infiltration of lymphocytes which was not seen in those with metal-onpolyethylene bearings. ${ }^{54}$ In a recent study, CD 20-positive B-lymphocytes and a distinct infiltration were found in the neocapsular tissue of 46 patients who had undergone revision of a metal-on-metal implant. ${ }^{55}$ In two cases, lymphatic follicles with both T- and B-lymphocytes were detected. Patients with RA and infection had been excluded and the median time until revision was only 14 months.

Pearle et $\mathrm{al}^{56}$ investigated lymphocyte gene expression in response to metal particles. They showed a non-specific innate activation of the immune system by polymethylmethacrylate particles whereas metal particles promoted induction of T-lymphocyte-specific gene expression.

Ladon et $\mathrm{al}^{57}$ showed a significant increase not only in serum levels of chromium and cobalt but also in chromosomal translocation and aneuploidy in peripheral blood lymphocytes at 6,12 and 24 months after implantation of a metal-on-metal prosthesis. Also, Hart et $\mathrm{al}^{58}$ showed a statistically significant decrease in the level of CD8+ T cells in asymptomatic patients after implantation of a metal-onmetal prosthesis which was well fixed. Theander et $\mathrm{al}^{20}$ found that patients who did not have an implant, but had Sjögren's syndrome with CD4+ T cell lymphocytopenia or a disturbed $\mathrm{CD} 4+/ \mathrm{CD} 8+$ ratio had a significantly-increased risk of later development of a lymphoma. Such a study has not been performed in patients with a metal-on-metal implant. It would be of value if a threshold could be established for serum levels of cobalt and chromium which would not cause lymphocytopenia in patients with a specific metal-on-metal bearing. Dunstan et al $^{59}$ studied 25 patients who received metal-on-metal bearings between 1965 and 1979 with a mean age at operation of 33 years and a mean follow-up of 35 years. They used the 24-colour fluorescent in situ hybridisation chromosomal painting technique on peripheral leucocytes to map chromosomal changes and aberrations. They found a significant difference in structural aberrations between a metal-onpolyethylene control group and the metal-on-metal group. Also, there were significantly more structural aberrations in the metal-on-metal group than in a revised metal-on-metal group after exchange to a conventional metal-onpolyethylene joint. There was no difference between the control and revised groups. Dunstan et $\mathrm{al}^{59}$ stated that the normal genetic repair mechanisms may be overloaded or damaged by the metal ion load.

The immune system can be subdivided into innate and adaptive systems. Macrophages, neutrophils and mast cells are the major active cells in the innate immune response to 
environmental agents such as metal ions. The adaptive system provides a memory for the original challenge and generates an enhanced response on re-exposure, largely through T and B cells. ${ }^{60}$

Follicular lymphoma is the second most common form of non-Hodgkin's lymphoma, accounting for approximately $25 \%$ of cases. ${ }^{61}$ Dave et $\mathrm{al}^{62}$ studied the gene expression profile in 191 biopsy specimens from patients with untreated follicular lymphoma. Unexpectedly, they found that the gene-expression signatures which predicted survival were derived from non-malignant cells in the tumour. This observation points to an important interplay between the host immune system and malignant cells. It is therefore possible that non-malignant lymph node cells, which include $\mathrm{T}$ cells, macrophages and follicular dendritic cells, promote proliferation of existing malignant cells.

Immunological high-risk factors for patients undergoing metal-on-metal implantation are therefore advanced RA, systemic chronic inflammation of connective tissue, ongoing anti-TNF treatment, severely impaired renal function and, in women, foreseeable pregnancy.

In conclusion, in patients with chronic systemic inflammatory conditions, there are no prospective studies which follow disease-activity lymphocyte function, measure ion concentrations and evaluate the risk of developing primary haematopoietic malignancy or lymphoma after metal-onmetal arthroplasties. Such studies are necessary to establish whether patients with high-risk factors should undergo such a procedure.

This study was supported by grants from the Swedish Association of Local Authorities and Regions (SALAR), the Faculty of Medicine, Lund University, the Swedish Research Council-Medicine (73X-09509) and Stiftelsen för bistånd åt rörelsehindrade i Skåne.

\section{References}

1. Delgado-Rodríguez M, Llorca J. Bias. J Epidemiol Community Health 2004;58:635-41.

2. Lewold S, OIsson H, Gustafson P, Rydholm A, Lidgren L. Overall cancer incidence not increased after prosthetic knee replacement: 14,551 patients followed for 66,622 person-years. Int J Cancer 1996;68:30-3.

3. Paavolainen P, Pukkala E, Pulkkinen P, Visuri T. Cancer incidence after total knee arthroplasty: a nationwide Finnish cohort from 1980 to 1996 involving 9,444 patients. Acta Orthop Scand 1999;70:609-17.

4. Olsen JH, McLaughlin JK, Nyrén 0, et al. Hip and knee implantations among patients with osteoarthritis and risk of cancer: a record-linkage study from Denmark. Int J Cancer 1999;81:719-22.

5. Gillespie WJ, Frampton CM, Henderson RJ, Ryan PM. The incidence of cancer following total hip replacement. J Bone Joint Surg [Br] 1988;70-B:539-42.

6. Visuri T, Pukkala E, Paavolainen P, Pulkkinen P, Riska EB. Cancer risk after metal on metal and polyethylene on metal total hip arthroplasty. Clin Orthop 1996;329 (Suppl):280-9.

7. Nyrén 0, McLaughlin JK, Gridley G, et al. Cancer risk after hip replacement with metal implants: a population-based cohort study in Sweden. J Natl Cancer Inst 1995;87:28-33

8. Visuri TI, Pukkala E, Pulkkiinen P, Paavolainen P. Cancer incidence and causes of death among total hip replacement patients: a review based on Nordic cohorts with a special emphasis on metal-on-metal bearings. Proc Inst Mech Eng [H] 2006;220:399-407.

9. Visuri T, Koskenvuo M. Cancer risk after Mckee-Farrar total hip replacement. Orthopedics 1991;14:137-42.

10. No authors listed. The Swedish Knee Arthroplasty Register. www.knee.se (date last accessed 11 October 2007).
11. No authors listed. The Swedish Hip Arthroplasty Register. www.jru.orthop.gu.se (date last accessed 11 October 2007).

12. No authors listed. Swedish Cancer Register http://www.socialstyrelsen.se/en/Statistics/Statistical-databases.htm (date last accessed 26 November 2007).

13. Askling J, Fored CM, Baecklund $\mathbf{E}$, et al. Haematopoietic malignancies in rheumatoid arthritis: lymphoma risk and characteristics after exposure to tumour necrosis factor antagonists. Ann Rheum Dis 2005;64:1414-20.

14. Baecklund E, Sundström C, Ekbom A, et al. Lymphoma subtypes in patients with rheumatoid arthritis: increased proportion of diffuse large B cell lymphoma. Arthritis Rheum 2003:48:1543-50.

15. Bäcklund E, Askling J, Rosenquist R, Ekbom A, Klareskog L. Rheumatoid arthritis and malignant lymphomas. Curr Opin Rheumatol 2004;16:254-61.

16. Whelan P. Link between rheumatoid arthritis and cancer. Z Rheumato/2006;65:497504 (in German).

17. Bernatsky S, Ramsey-Goldman R, Clarke A. Malignancy and autoimmunity. Curr Opin Rheumatol 2006;18:129-34.

18. Theander E, Manthorpe R, Jacobsson LT. Mortality and causes of death in primary Sjogren's syndrome: a prospective cohort study. Arthritis Rheum 2004;50:1262-

19. Pillemer SR. Lymphoma and other malignancies in primary Sjögren's syndrome. Ann Rheum Dis 2006;65:704-6.

20. Theander E, Henriksson $\mathbf{G}$, Ljungberg $\mathbf{0}$, et al. Lymphoma and other malignancies in primary Sjögren's syndrome: a cohort study on cancer incidence and lymphoma predictors. Ann Rheum Dis 2006;65:796-803.

21. Heath JC, Freeman MA, Swanson SA. Carcinogenic properties of wear particles from prostheses made in cobalt-chromium alloy. Lancet 1971;1:564-6.

22. Rae T. The haemolytic action of particulate metals ( $\mathrm{Cd}, \mathrm{Cr}, \mathrm{Co}, \mathrm{Fe}, \mathrm{Mo}, \mathrm{Ni}, \mathrm{Ta}$, Ti, Zn, Co-Cr alloy). J Pathol 1978;125:81-9.

23. Snow ET. Metal carcinogenesis: mechanistic inmplications. Pharmacol Ther 1992;53:31-65

24. Sunderman FW Jr. Recent advances in metal carcinogenesis. Ann Clin Lab Sci 1984;14:93-122.

25. Goodman S, Aspenberg P, Song Y, et al. Tissue ingrowth and differentiation in the bone-harvest chamber in the presence of cobalt-chromium-alloy and high-densitypolyethylene particles. J Bone Joint Surg [Am] 1995;77-A:1025-35.

26. Steens W, von Foerster G, Katzer A. Severe cobalt poisoning with loss of sight after ceramic-metal pairing in a hip: a case report. Acta Orthop 2006;77:830-2.

27. Cobb AG, Schmalzreid TP. The clinical significance of metal ion release from cobalt-chromium metal-on-metal hip joint arthroplasty. Proc Inst Mech Eng [H] 2006;220:385-98

28. Sargeant A, Goswami T, Swank M. Ion concentrations from hip implants. J Surg Orthop Adv 2006;15:113-4.

29. Virtanen S. Metal release mechanisms in hip replacement. Acta Orthop 2006;77:695-6.

30. McDonald SJ. Can a safe level for metal ions in patients with metal-on-metal total hip arthroplasties be determined? J Arthroplasty 2004;19(Suppl 3):71-7.

31. Keegan GM, Learmonth ID, Case CP. Orthopaedic metals and their potential toxicity in the arthroplasty patient: a review of current knowledge and future strategies. J Bone Joint Surg [Br] 2007;89-B:567-73.

32. Rae T. The toxicity of metals used in orthopaedic prostheses: an experimental study using cultured human synovial fibroblasts. J Bone Joint Surg [Br] 1981;63-B:435-40.

33. MacDonald SJ, Brodner W, Jacobs JJ. A consensus paper on metal ions in metal-on-metal hip arthroplasties. J Arthroplasty 2004;19(Suppl 3):12-16.

34. Daniel J, Ziaee H, Pynsent PB, McMinn DJ. The validity of serum levels as a surrogate measure of systemic exposure to metal ions in hip replacement. J Bone Joint Surg [Br] 2007;89-B:736-41

35. Cuckler JM. The rationale for metal-on-metal total hip arthroplasty. Clin Orthop 2005;441:132-6.

36. Daniel J, Ziaee H, Pradhan C, Pynsent PB, McMinn DJ. Blood and urine metal ion levels in young and active patients after Birmingham hip resurfacing arthroplasty: four-year results of a prospective longitudinal study. J Bone Joint Surg [Br] 2007;89B:169-73.

37. Back DL, Young DA, Shimmin AJ. How do serum cobalt and chromium levels change after metal-on-metal hip resurfacing? Clin Orthop 2005;438:177-81.

38. Brodner W, Bitzan P, Meisinger V, et al. Serum cobalt levels after metal-on-metal total hip arthroplasty. J Bone Joint Surg [Am] 2003;85-A:2168-73.

39. Case CP, Ellis L, Turner JC, Fairman B. Development of a routine method for the determination of trace metals in whole blood by magnetic sector inductively coupled plasma mass spectrometry with particular relevance to patients with total hip and knee arthroplasty. Clin Chem 2001;47:275-80.

40. Saikko V, Nevalainen J, Revitzer H, Ylinen P. Metal release from total hip articulations in vitro: substantial from $\mathrm{CoCr} / \mathrm{CoCr}$ negligible from $\mathrm{CoCr} / \mathrm{PE}$, and alumina/ PE. Acta Orthop Scand 1998;69:449-54. 
41. Savarino L, Granchi D, Ciapetti G, et al. Ion release in patients with metal-on-metal hip bearings in total joint replacement: a comparison with metal-on-polyethylene bearings. J Biomed Mater Res 2002;63:467-74

42. Savarino L, Greco M, Cenni E, et al. Differences in ion release after ceramic-onceramic and metal-on-metal total hip replacement: medium-term follow-up. J Bone Joint Surg [Br] 2006;88-B:472-6.

43. Silva M, Heisel C, Schmalzried TP. Metal-on-metal total hip replacement. Clin Orthop 2005;430:53-61.

44. Sauvé P, Mountney J, Khan T, et al. Metal ion levels after metal-on-metal Ring tota hip replacement: a 30-year follow-up study. J Bone Joint Surg [Br] 2007;89-B:586-90.

45. Dunstan E, Sanghrajka AP, Tilley S, et al. Metal ion levels after metal-on-metal proximal femoral replacements: a 30-year follow-up. J Bone Joint Surg [Br] 2005;87B:628-31.

46. Khan M, Takahashi T, Kuiper JH, et al. Current in vivo wear of metal-on-metal bearings assessed by exercise-related rise in plasma cobalt level. J Orthop Res 2006:24:2029-35

47. De Haan R, Campbell P, Reid S, Skipor AK, De Smet K. Metal ion levels in a triathlete with a metal-on-metal resurfacing arthroplasty of the hip. J Bone Joint Surg $[\mathrm{Br}]$ 2007:89-B:538-41.

48. Clarke MT, Lee PT, Arora A, Villar RN. Levels of metal ions after small- and largediameter metal-on-metal hip arthroplasty. J Bone Joint Surg [Br]2003;85-B:913-7.

49. Witzleb WC, Ziegler J, Krummenauer F, Neumeister V, Guenther KP. Exposure to chromium, cobalt and molybdenum from metal-on-metal total hip replacement and hip resurfacing arthroplasty. Acta Orthop 2006;77:697-705.

50. Vendittoli PA, Mottard S, Roy AG, Dupont C, Lavigne M. Chromium and cobalt ion release following the Durom high carbon content, forged metal-on-metal surface replacement of the hip. J Bone Joint Surg [Br]2007;89-B:441-8.

51. Ziaee H, Daniel J, Datta AK, Blunt S, McMinn DJ. Transplacental transfer of cobalt and chromium in patients with metal-on-metal hip arthroplasty: a controlled study. $J$ Bone Joint Surg [Br] 2007;89-B:301-5.
52. Grübl A, Marker M, Brodner W, et al. Long-term follow-up of metal-on-metal total hip replacement. J Orthop Res 2007;25:841-8.

53. Catelas I, Campbell PA, Bobyn JD, Medley JB, Huk OL. Wear particles from metal-on-metal total hip replacements: effects of implant design and implantation time. Proc Inst Mech Eng [H]2006;220:195-208.

54. Davies AP, Willert HG, Campbell PA, Learmonth ID, Case CP. An unusual lymphocytic perivascular infiltration in tissues around contemporary metal-on-metal joint replacements. J Bone Joint Surg [Am] 2005;87-A:18-27.

55. Witzleb WC, Hanisch U, Kolar N, Krummenauer F, Guenther KP. Neo-capsule tissue reactions in metal-on-metal hip arthroplasty. Acta Orthop 2007;78:211-20.

56. Pearle AD, Crow MK, Rakshit DS, Wohlgemuth J, Nestor BJ. Distinct inflammatory gene pathways induced by particles. Clin Orthop 2007;458:194-201.

57. Ladon D, Doherty A, Newson R, et al. Changes in metal levels and chromosome aberrations in the peripheral blood of patients after metal-on-metal hip arthroplasty. J Arthroplasty 2004;19 (Suppl 3):78-83.

58. Hart AJ, Hester T, Sinclair K, et al. The association between metal ions from hip resurfacing and reduced T-cell counts. J Bone Joint Surg [Br] 2006;88-B:449-54.

59. Dunstan E, Ladon D, Whittingham-Jones P. Chromosomal aberrations in the peripheral blood of patients with metal-on-metal hip bearings. Procs British Orthopaedic Association Annual Congress, 2006.

60. Stenstad H. Effector T cell homing to the small intestinal mucosa. Department of Experimental Medical Science, Section for Immunology. Doctoral dissertation. Lund: Lund University, 2007.

61. Armitage J0, Weisenburger DD. New approach to classifying non-Hodgkin's lymphomas: clinical features of the major histologic subtypes. J Clin Oncol 1998;16:2780-

62. Dave SS, Wright G, Tan B, et al. Prediction of survival in follicular lymphoma based on molecular features of tumor-infiltrating immune cells. $N$ Engl $\mathrm{J}$ Med 2004;351:2159-69. 